\title{
Introduction to the Digital and ICT Enabled Services Minitrack
}

\author{
Tilo Böhmann \\ Universität Hamburg \\ Department of Informatics \\ tilo.boehmann@uni-hamburg.de
}

\author{
Ola Henfridsson \\ University of Warwick Warwick \\ Business School \\ ola.henfridsson@wbs.ac.uk
}

\author{
Tuure Tuunanen \\ University of Jyväskylä \\ Faculty of IT \\ tuure@tuunanen.fi
}

This minitrack deals with the innovation, design, development, management, and use of Digital and ICT Enabled Services for both consumers and enterprises. It provides a forum for fostering service-based approaches. It also offers an opportunity to present and debate design and theory-based solutions to problems facing industry in the deployment of digital and ICT enabled services [1-4]. We define ICT enabled services as [1]: “..systems that enable value cocreation through the development and implementation of information and communication technology enabled processes that integrate system value propositions with customer value drivers."

ICT enabled services go beyond the well-known web-based services. Examples that meld the worlds of bits and atoms include intelligent frequent flyer cards that facilitate check-in and identity verification, mobile ticketing services for public transport, co-creation services for music festival participants, smart television services and contents, tablet-based food and drink ordering services, and so on.

This emerging area of research raises interesting questions. For example, traditional development approaches focus on improving the efficiency and effectiveness of organizational processes. The design of ICT enabled services may, however, require an emphasis on the socio-psychological aspects, such as the value-in-use and user/consumer/co-creator experiences. As consumer and enterprise personnel became cocreators of value, a significant re-appraisal of our current design and development approaches is motivated. Relevant topics for this minitrack include, e.g., discovery, fuzzy-front end, innovation processes and methodologies for design, and development, analytics-supported innovation, design, and development, sociopsychological aspects of ICT enabled services, service ecosystems, social networking and location aware services, hedonic ICT enabled services, and finally understanding social and cultural contexts of consumerization of consumer and enterprise services.

The papers included in this year's minitrack cover topics such as digital service innovation enabled by big data analytics, a service-dominant logic perspective, and examinations of value-in-context in service innovation. The first paper reviews the literature of digital service innovations and explores how big data analytics can contribute along the different dimensions of digital service innovations. The second paper applies conjoint analysis to understand the perceived value of innovative digital services. The third paper examines consumer information services [1] in intercultural tourism in the case of Chinese outbound backpackers. This study applies an ethnographic research approach, which is still fairly uncommon in information systems research. We also welcome a more technical article that looks at stateful SOA-conformant services as building blocks for interactive software services.

\section{References}

[1] T. Tuunanen, M. Myers, and H. Cassab, "A Conceptual Framework for Consumer Information Systems Development," Pacific Asia Journal of the Association for Information Systems, vol. 2, pp. 4766, 2010.

[2] K. N. Lemon and M. H. Huang, "IT-Related Service: A Multidisciplinary Perspective," Journal of Service Research, vol. 14, p. 251, August 2011.

[3] I. R. Bardhan, H. Demirkan, P. Kannan, and R. J. Kauffman, "Special Issue: Information Systems in Services," Journal of Management Information Systems, vol. 26, pp. 5-12, 2010.

[4] T. Böhmann, J. M. Leimeister, and K. Möslein, "Service Systems Engineering: A field for future Information Systems Research," Business Information Systems Engineering, vol. 6(2), pp. 7379, 2014. 